\title{
The Practice Degree of University Academic Leaderships in Jordan Private Universities within Amman Governorate for Administrative Empowerment and Its Relationship to the Level of Competitive Advantage and the Faculty Members' Points of View
}

\author{
Dr. Jamal Mohammad Al-Orimi \\ Ministry of Education - Jordan \\ Phone: 00962779032310 - Email Alorimij@gmail.com
}

\begin{abstract}
:
The study aimed to reveal the relationship between the degree of academic leaderships in Jordan private universities within Amman Governorate for administrative empowerment and its relationship to the level of competitive advantage and the faculty members' points of view. and the sample was consisted of (337) faculty members, The results showed that the total score for the practice of administrative empowerment, obtained a general average of (4.10) and a high degree. At the level of the fields, the field of delegation of authority obtained the highest average (4.22), the field of participation in decision-making obtained (4.19), the field of selfmotivation obtained (4.06), the field of effective communication with an average of (3.95), and the level of competitive advantage got an average (3.94) with a high degree. The results indicated that there is a positive correlation relationship with statistical significance between the total score of Kane administrative, the overall degree of the level of competitive advantage. In addition, there were no statistically significant differences in the degree of administrative empowerment exercise referring to a variable (Academic rank and experience), While there were statistically significant differences referring to the gender variable especially for the male group. There were no differences appeared with statistical significance in the level of competitive advantage due to variables (gender, academic rank, and experience).
\end{abstract}

Keywords: Academic leaderships, Jordan private Universities, administrative empowerment, competitive advantage.

DOI: $10.7176 / \mathrm{JEP} / 11-27-05$

Publication date:September $30^{\text {th }} 2020$

\section{Introduction}

The world has been experiencing several rapid changes. Such changes increased the severity of the global competition between various private and public organizations. That applies to service and manufacturing organizations. Hence, organizations have been exerting much effort to keep up with the latest developments and handle challenges. In addition, many organizations started using various methods that provide attention to human resources. That's because human resources have significant impact on the organizational success level.

The administrative empowerment of academic leaders in universities has major positive impacts. For instance, it contributes to improving services, and raising the effectiveness of the communication between the university and its beneficiaries. It contributes to solving problems without having to wait for solving them by the top management. It contributes to improving the capabilities of academic leaders and raising the extent of believing in themselves. It contributes to promoting creativity and team spirit among academic leaders. It contributes to promoting a sense of responsibility among academic leaders and increasing their loyalty to the universities they work at (Abd al-Hadi and Hatat, 2012: 227).

Administrative empowerment may be defined as an administrative process in the organization that involves giving administrative powers by leaders to their subordinates in order to do their functions, handle their responsibilities and make decisions on behalf of them. It is practiced in the aim of developing the members of the team professionally and motivating them to show a better performance. It aims at creating a convenient work environment. It aims at meeting the intended goals (Al-Shetikhi, 2016).

Administrative empowerment may be defined as the process of delegating powers and assigning responsibilities to subordinates by leaders. It also involves engaging subordinates in the decision making process. It aims at meeting the intended goals of the organization (Smith and Greyling, 2006: 596). It is considered very important. That is because it develops employees professionally to become capable of handling problems and risks, especially when the managers and decisions makers are absent. Administrative empowerment creates a convenient workplace environment that enables employees to make the right decisions. This environment enables employees to find effective solutions for problems. It enables employees to develop their potentials and capabilities (AlDughmi, 2019).

Jallab and Al-Hussaini (2013) suggests that administrative empowerment is very significant in the age of globalism. They suggest that administrative empowerment is beneficial for organizations and employees. For 
instance, administrative empowerment promotes loyalty among employees and contributes to meeting their basic needs. It promotes task significance among employees. It motivates employees to work. It makes working enjoyable for employees. It makes work meaningful. It increases the performance effectiveness and efficiency of the organization. It accelerates the processes of making decisions and suggestions. It improves and accelerates the service delivery process (Jallab and Al-Hussaini, 2013).

There are several obstacles that hinder leaders from practicing administrative empowerment. Such obstacles include: adopting a centralized approach and having conventional organizational structures. They include: showing resistance to change and having a poor organizational culture. They include: fear of facing risks. They include: failure in forming teams at workplace. They include: the incapability to collaborate between the members of the team at the workplace (Wadi, 2013).

Achieving a competitive advantage age has been sought by all organizations in general and universities in particular. It has been sought to handle challenges effectively and win the competition against competitors. It can be achieved through having highly qualified human resources who have excellent skills and much expertise. It requires being capable to utilize the expertise of human resources effectively and efficiently. It requires meeting the needs of customers in a quick and ongoing manner (Al- Shammari, 2018).

A competitive advantage refers to the thing that makes the organization different from other organizations. Achieving a competitive advantage enables the organization to excel and compete effectively. It is affected by several factors. It enables the organizations to make a good reputation and attract customers (Taleb, 2012).

Pitts \& Lee (1996) suggest that achieving a sustainable competitive advantage requires having human resources who have excellent. Failure to achieve a sustainable competitive advantage shall hinder the organization from survival in the market and compete with others (Pitts \& Lee, 1996).

Al-Shammari (2014) defines the competitive advantage as the capability of the organization to produce unique products or deliver unique services. Competitors must face difficulty in making products or delivering services of the same quality or quantity (Al-Shammari, 2014). A competitive advantage refers to the capability of the organization to develop and implement strategies that make it better than its competitors who operate in the same field. Achieving a competitive advantage requires utilizing human, financial and tangible resources efficiently and effectively. It requires having human resources who have much knowledge and expertise. It enables organizations to develop and implement effective strategies (Abd al-Hadi, 2014).

Scholars have developed several technologies that enable organizations to develop. Hence, the achievement of a competitive advantage has been serving as a mean for handling the challenges in the market and keep up with developments. It reflects how successful the organization is. It serves as a goal that all organizations have been seeking to meet. It enables organization to survive and develop. It reflects the extent of meeting the requirements of achieving organizational success (Taleb, 2012).

The organizations that seek achieving a competitive advantage keep seeking meeting the needs and demands of customers. They keep exerting efforts to win the competition in the market. They seek opening new sales channels and reducing costs. They keep providing attention to the development of human resources. They seek making changes to their strategies and structure in order to adjust themselves with the changes (Hill and Jones, 2008). Achieving a competitive advantage requires dedicating much time. It requires providing something that competitors can't provide to customers (Porter, 2006: 48).

Turning the competitive advantage into a sustainable competitive advantage is a goal sought by all organizations. There are several important factors that affect the capability of organizations to achieve a competitive advantage. Such factors include: organizational agility, meeting the beneficiaries' needs, quality, creativity and efficiency (Hill and Jones, 2008). In the light of the aforementeiond information, the present study aimed to explore the extent of practicing administrative empowerment by academic leaders in Jordanian private universities. It aimed to explore the relationship between the extent of practicing administrative empowerment by academic leaders from one hand and the achievment of a competitive advantage from another hand in private universities in Amman, Jordan. It aimed to explore that from the perspective of faculty members.

\section{Statement of the Problem}

The problem of the present study is represented in exploring the relationship between the extent of practicing administrative empowerment by academic leaders from one hand and the achievment of a competitive advantage in private universities in Amman, Jordan from another hand from the perspective of faculty members. After reviewing the relevant studies, it was found that there is a need to conduct a study about this problem. In order for universities to meet their goals, they must use modern administrative methods. They must provide support to their employees. They must create a convenient work environment for employees. That is because employees play a significant role in achieving development and excellence in universities. It is because employees play a significant role in achieving a competitive advantage. To be more specific, the present study aimed to provide answers to the following questions:

Q.1. What is the extent of practicing administrative empowerment by academic leaders in private universities in 
Amman, Jordan from the persepctive of faculty members?

Q.2. What is the extent of achieving a competitive advantage by academic leaders in private universities in Amman, Jordan from the persepctive of faculty members?

Q.3. Is there any significant relationship -at the statistical significance level of $(a=0.05)$ - between the extent of practicing administrative empowerment by academic leaders from one hand and the achievment of a competitive advantage in private universities in Amman, Jordan from another hand from the perspective of faculty members? Q.4. Is there any statistically significant difference-at the statistical significance level of $(\mathrm{a}=0.05)$ - between the respondents' attitudes towards administrative empowerment which can be attributed to (gender, rank or experience)?

Q.5. Is there any statistically significant difference-at the statistical significance level of ( $\mathrm{a}=0.05)$ - between the respondents' attitudes towards achieving a competitive advantage which can be attributed to (gender, rank or experience)?

\section{The Study's Objectives:}

\section{The present study aimed to:}

1)- Identify the extent of practicing administrative empowerment by academic leaders in private universities in Amman, Jordan from the persepctive of faculty members.

2)- Identify the extent of achieving a competitive advantage by academic leaders in private universities in Amman, Jordan from the persepctive of faculty members.

3)- Identify whether there is any statistically significant relationship -at the statistical significance level of $(a=0.05)$ - between the extent of practicing administrative empowerment by academic leaders from one hand and the achievment of a competitive advantage in private universities in Amman, Jordan from another hand from the perspective of faculty members.

4)- Identify whether there is any statistically significant difference-at the statistical significance level of $(a=0.05)$ between the respondents' attitudes towards administrative empowerment which can be attributed to (gender, rank or experience).

5)- Identify whether there is any statistically significant difference-at the statistical significance level of $(a=0.05)$ between the respondents' attitudes towards achieving a competitive advantage which can be attributed to (gender, rank or experience).

\section{The Study's Significance:}

The present study is significant because it offers significant results. It is significant because it is beneficial for the following ones:

- Management of universities: The results of the present study enable the management of universities to achieve a competitive advantage

- Decision makers in Jordanian universities: The results of the present study enable decision makers at Jordanian universities to activate the role of academic leaders in Jordanian universities.

- $\quad$ Researchers: The present study provides researchers with a theoretical framework and a review of empirical studies that facilitate the process of conducting similar studies

\section{Definition of Terms:}

\section{The study's terms are defined below}

Administrative empowerment (theoretical definition): It refers to an administrative process that involves granting subordinates the right to act on behalf of their leaders. It involves granting powers to subordinates and providing them with the required information on the right time. It involves granting subordinates the right to choose the way they want to carry out their works (Al-Kubaisi et al., 2017: 3). It may be defined as granting individuals greater powers related to control, handling responsibilities and using their capabilities. It involves authorizing subordinates to make decisions (Badah, 2012: 14).

Administrative empowerment (Operational definition): It refers to the extent of practicing administrative empowerment by academic leaders in private universities in Amman, Jordan. It is measured through using the study's questionnaire.

Competitive advantage (theoretical definition): It is represented in the capability of the organization to offer customer products or services that are unique and can't be offered by competitors. It enables organizations to survive (Wheelen and Hunger, 2012).

Competitive advantage (operational definition): It refers to the perceptions of faculty members at private universities in Amman, Jordan towards the achievement of a competitive advantage. It is measured through the study's questionnaire.

The Study's Limits:

The present study was conducted during the academic year (2019/2020). It targets faculty members in Jordanian 
private universities

Previous Studies:

This part presents the studies that were reviewed by the researchers.

Weshah (2012) aimed to explore the extent of empowering teachers and delegating powers to them in Jordanian and Australian schools. He aimed to explore that from the perspective of teachers in Jordanian and Australian schools. The population is represented in all the Jordanian and Australian schools. The researcher selected a sample that consists from 188 teachers. Those teachers were selected from several Jordanian and Australian schools. It was found that the extent of empowering teachers and delegating powers to them is moderate. It was found that there isn't any statistically significant difference between the respondents' attitudes which can be attributed to gender, academic qualification or service.

Al-Zamili (2015) aimed to explore the extent of practicing administrative empowerment by secondary school principals in Gaza. He aimed to explore the relationship between practicing administrative empowerment the job satisfaction among secondary school principals in Gaza. To meet the study's goals, a descriptive analytical approach was adopted. A questionnaire was used for collecting the relevant data. The sample consists from 129 female and male principals. It was found that the extent of practicing administrative empowerment by secondary school principals in Gaza is high. It was found that there is a statistically significant positive correlation between practicing administrative empowerment the job satisfaction among secondary school principals in Gaza. It was found that there are statistically significant differences between the respondents' attitudes towards the extent of practicing administrative empowerment which can be attributed to experience. The latter differences are for the favor of the ones who have 10 years of experience. It was found that there isn't any statistically significant difference between the respondents' attitudes towards the extent of practicing administrative empowerment which can be attributed to gender nor academic qualification

Al-Hamidi (2016) aimed to explore the organizational loyalty and empowerment levels of the faculty members at the faculty of education at Ta'ef University from their perspective. He aimed to explore the relationship between organizational loyalty and empowerment levels of the faculty members at the faculty of education from their perspective. To meet the intended goals, a descriptive analytical approach was adopted. A questionnaire was used for collecting data. It was found that the empowerment level of the faculty members at the faculty of education at Ta'ef University is moderate. It was found that the organizational loyalty level of the faculty members at the faculty of education at Ta'ef University is moderate. It was found that there is a statistically significant relationship between organizational loyalty and empowerment levels of the faculty members at the faculty of education from their perspective. It was found that there isn't any statistically significant difference between the empowerment levels of the faculty members at the faculty of education which can be attributed to academic rank and experience. It was found that there is a statistically significant difference between the empowerment levels of the faculty members at the faculty of education which can be attributed to gender.

Al- Salahat (2017) aimed to explore the relationship between the administrative empowerment and competitive advantage from the perspective of faculty members at the Middle East University. To meet the study's goals, a descriptive correlative approach was adopted. A questionnaire was used to collect the relevant information. The sample consists from 92 faculty members. It was found that the administrative empowerment and competitive advantage levels are moderate. It was found that there is a statistically significant difference between the respondents' attitudes towards administrative empowerment which can be attributed to gender. The latter difference is for the favor of males. It was found that there is a statistically significant difference between the respondents' attitudes towards administrative empowerment which can be attributed to experience. The latter difference is for the favor of the ones whose experience is 10 years or more. It was found that there isn't any statistically significant difference between the respondents' attitudes towards administrative empowerment which can be attributed to faculty, or academic rank. It was found that there is a statistically significant difference between the respondents' attitudes towards competitive achievement which can be attributed to gender for the favor of males. It was found that there is a statistically significant difference between the respondents' attitudes towards competitive achievement which can be attributed to faculty. The latter difference is for the favor of the ones who work in scientific faculties. It was found that there isn't any statistically significant difference between the respondents' attitudes towards competitive achievement which can be attributed to experience or academic rank.

Chang (2016) aimed to identify the effect of environmental ethics on competitive advantage, in addition to identifying the mediating role of green innovation in a sample of Taiwanese factories. (500) questionnaires were distributed to executives who work on environmental protection, marketing, production, human resources. And research and development. The study found that the ethics of the company's environment positively affects the green creativity of the product, in addition to that the green creativity of the product mediates a positive relationship between the ethics of the company's environment and achieving the competitive advantage in addition to that the ethics of the company's environment does not directly affect the achievement of competitive advantage, but rather affects significantly. Indirectly through the green creativity of the product.

Al Hilaa et al (2017) aimed to identify the institutional excellence in the Palestinian universities operating in 
the Gaza Strip from the point of view of the supervisory higher administrations in the universities, and to achieve this, the researcher relied on the use of the descriptive and analytical method, and a questionnaire was distributed to the study sample of which they are (182) Palestinian university employees, and the study found that university administrations agree that there is leadership distinction and distinction in the service sectors, in addition to a weak point represented by the failure of university administrations to follow up on their graduates in terms of their future career.

Al-Shammari (2018) aimed to determine the impact of administrative empowerment represented by sharing power, exchanging information and work teams and expanding powers in achieving competitive capabilities at Kuwait University from the viewpoint of the faculty members, and in order to achieve the objectives of the study, a questionnaire was developed and distributed to (465) ) A faculty member, chosen in a simple random way, and the study found that the degree of administrative empowerment practice in Kuwait University from the faculty members 'point of view was of a moderate degree, and that the level of competitive capabilities of Kuwait University from the faculty members' point of view came to a high degree. The study indicated that there is a statistically significant effect of areas of administrative empowerment on the competitiveness capabilities of Kuwait University, and the study concluded that there are statistically significant differences in the respondents 'perceptions of the level of empowerment of workers according to the variables of gender and scientific rank, and the results showed that there were no statistically significant differences in the respondents' perceptions of the level of empowerment of workers according to different variables. Years of experience and job title variable.

\section{Comments on the aforementioned studies:}

At the end of the presentation of previous studies, it can be said that these studies are directly related to the subject of the study, which is administrative empowerment and competitive advantage, as they all agreed on the necessity of adopting administrative empowerment and competitive advantage in developing the work of institutions. The degree of practicing academic leaderships in private Jordanian universities in the Amman governorate for administrative empowerment and the degree of practicing competitive advantage for faculty members from their point of view.

\section{Methods and Procedures:}

\section{The Study's Approach:}

This study aims to find out the relationship between the degree of academic leadership practice in private Jordanian universities in Amman governorate for administrative empowerment and the level of practicing competitive advantage for faculty members, and to achieve this goal, the descriptive correlative survey approach was used.

\section{The Study's Population and Sample:}

The study population included all faculty members in private Jordanian universities in the capital Amman governorate, whose number is (1798) faculty members, and according to the statistics issued by the Ministry of Higher Education, for the academic year (2017/2018), and a random sample of (337) was selected ) A faculty member from three universities (Al-Ahliyya Amman Private University, Applied Science Private University, and Al-Zaytoonah Private University of Jordan).

\section{The Study's Instrument:}

Based on the relevant literature and the study questions and objectives, the researcher developed the study a tool. The study tool is represented in a closed questionnaire that aims to collect data from Respondents. It sheds light on two areas. These areas are listed below:

The first area: related to the degree of practicing administrative empowerment.

The second area: related to the level of practicing competitive advantage.

For the purposes of statistical analysis, the study data were given the following scores for reality items according to the five-point Likert scale: one score for responding with a very small degree, two degrees for responding with a low degree, three scores for responding with a moderate degree, four scores for responding with a high degree, and five degrees for responding with a very high degree.

\section{The validity of the instrument:}

To measure the study's validity, the initial version of the questionnaire was passed to (11) experts who are specialized in the educational field. Those experts were asked to assess the questionnaire in terms of language, relevancy, and clarity. They were asked to provide their comments. It was found that more than $80 \%$ of the experts recommend keeping all the items. However, some experts recommended re-drafting the items. None of the experts recommended deleting any item in the questionnaire nor adding any item to it. 


\section{The reliability of the instrument:}

In order to ensure that the questionnaire measures the factors to be measured, and to verify its validity, the researcher conducted a test for the internal consistency of the scale paragraphs, where the coherence of the scale was evaluated by calculating the Cronbach-Alpha coefficient, and he indicated the strength of the link and the cohesion between the scale paragraphs. The stability factor of the tool $(0.90)$, and this ratio is sufficient for the purposes of this study.

\section{Statistical analysis:}

The data was analyzed statistically through using descriptive statistical methods and the SPSS program. To answer the first and second questions, arithmetic averages, and standard deviations are calculated. The Pearson correlation coefficient values are calculated and the t-test was conducted. In addition, the one way analysis of variance (ANOVA) was conducted.

\section{Results and Discussion:}

\section{Results related to the first question}

Q.1. What is the extent of practicing administrative empowerment by academic leaders in private universities in Amman, Jordan from the persepctive of faculty members?

To answer this question, arithmetic averages and standard deviations are calculated. They are presented in table (1) below:

Table (1): The extent of practicing administrative empowerment by academic leaders in private universities in Amman, Jordan from the persepctive of faculty members

\begin{tabular}{|c|l|c|c|c|l|}
\hline No. & \multicolumn{1}{|c|}{ Area } & Mean & Std. & Rank & \multicolumn{1}{|c|}{ Level } \\
\hline 3 & Delegation of authority. & 4.22 & 0.8 & 1 & Very high \\
\hline 2 & Participating in the decision-making process & 4.19 & 0.8 & 2 & High \\
\hline 4 & Self-motivation. & 4.06 & 0.9 & 3 & High \\
\hline 1 & Effective Communication. & 3.95 & 0.9 & 4 & High \\
\hline \multicolumn{2}{|c|}{ Total } & $\mathbf{4 . 1 0}$ & $\mathbf{0 . 8}$ & - & High \\
\hline
\end{tabular}

Based on table (1), the extent of practicing administrative empowerment by academic leaders in private universities in Amman, Jordan from the persepctive of faculty members is high. That is because the ovearll maean is 4.10. The total standard deviation is (0.8). The mean of the delegation of authority area is 4.22 and ranked first. The mean of participating in decision-making area is 4.19 and ranked second. The mean of the self-motivation area is 4.06 and ranked third. The mean of the effective communication area is 3.95 and ranked fourth.

The researcher attributes the latter result to having much awareness among academic leaders in private Jordanian universities about the role of administrative empowerment in enhancing the effectiveness of the administrative performance. For instance, administrative empowerment contributed to accelerating the completion of tasks and promoting a sense of initiative. It enables employees to do their tasks efficiently. It provides employees with more freedom when making choices. The results in this regard are consistent with the result concluded by AL-Haroot (2018) and Al-Zamili (2015).

The extent of practicing administrative empowerment by academic leaders in private universities in Amman, Jordan from the persepctive of faculty members is illustrated below in each area:

The first area: delegation of authority

Table (2): The extent of delegating authority by academic leaders in private universities in Amman, Jordan from the persepctive of faculty members

\begin{tabular}{|c|l|c|c|c|c|}
\hline No. & \multicolumn{1}{|c|}{ Area } & Mean & Std. & Rank & Degree \\
\hline 3 & Delegating academic leaderships based on regulations. & 4.60 & 0.82 & 1 & Very high \\
\hline 5 & $\begin{array}{l}\text { The mandate of academic leaders gives discretion in the } \\
\text { performance of their tasks. }\end{array}$ & 4.57 & 1.03 & 2 & Very high \\
\hline 1 & $\begin{array}{l}\text { The university trusts in the capabilities of academic leaders to } \\
\text { perform the tasks assigned to them. }\end{array}$ & 4.44 & 1.06 & 3 & Very high \\
\hline 2 & $\begin{array}{l}\text { Academic leaderships are given adequate time to carry out the } \\
\text { tasks assigned to them. }\end{array}$ & 3.85 & 0.81 & 4 & high \\
\hline 4 & $\begin{array}{l}\text { The university determines the work delegated to academic leaders } \\
\text { in writing. }\end{array}$ & 3.64 & 1.08 & 5 & high \\
\hline \multicolumn{1}{|l}{ Total } & $\mathbf{4 . 2 2}$ & $\mathbf{0 . 8}$ & & Very high \\
\hline
\end{tabular}

Based on table (2), the means are within the range of (4.60-3.64). Statement (3) states the following "the delegation of academic leaderships to faculty members based on the systems". The mean of the latter statement is (4.60) which is very high. The latter result is attributed to the fact that the academic leaders employ organized administrative method, and comply with regulations. The results in this regard are consistent with the results 
concluded by Al-Zamili (2015). They indicate that administrative empowerment is practiced out in accordance with the applicable regulations and instruction.

Statement (4) states the following: "academic leaders define the work delegated to academic leaders in writing". The mean of the latter statement is (3.64) which is high. The latter result is attributed to the fact that academic leaders still use verbal methods to some extent. The result in this regard is inconsistent with the result concluded by Al-Salaha (2017).

The second area: Participation in the decision-making process.

Arithmetic mean, and standard deviations are calculated to identify the extent of practicing administrative empowerment by academic leaders in private universities in Amman, Jordan in terms of participation in the decision-making process. Table (3) presents those values.

Table (3): The extent of practicing administrative empowerment by academic leaders in private universities in Amman, Jordan in terms of participation in the decision-making process

\begin{tabular}{|c|l|c|c|c|c|}
\hline No. & \multicolumn{1}{|c|}{ Area } & Mean & Std. & Rank & Degree \\
\hline 2 & $\begin{array}{l}\text { The university trusts in the capabilities of academic leaders to make } \\
\text { decisions. }\end{array}$ & 4.61 & 0.83 & 1 & $\begin{array}{l}\text { Very } \\
\text { high }\end{array}$ \\
\hline 1 & $\begin{array}{l}\text { Academic leaders possess the skills to participate in the decision- } \\
\text { making process. }\end{array}$ & 4.44 & 0.67 & 2 & $\begin{array}{l}\text { Very } \\
\text { high }\end{array}$ \\
\hline 4 & $\begin{array}{l}\text { Participation in decision-making is characterized by providing } \\
\text { positive relationships with academic leaders. }\end{array}$ & 4.40 & 1.00 & 3 & $\begin{array}{l}\text { Very } \\
\text { high }\end{array}$ \\
\hline 3 & The university respects the decisions made by academic leaders. & 4.11 & 0.81 & 4 & high \\
\hline 5 & $\begin{array}{l}\text { Academic leaders are responsible for implementing the decisions } \\
\text { they co-made. }\end{array}$ & 3.39 & 0.92 & 5 & Moderate \\
\hline \multicolumn{1}{|l}{ Total } & $\mathbf{4 . 1 9}$ & $\mathbf{0 . 8}$ & & high \\
\hline
\end{tabular}

Based on table (3), the means are within the range of (4.61-3.39). Statement (2) states the following: "academic leaders have confidence in the abilities of faculty members to make decisions". The mean of the latter statement is (4.61) which is very high. The latter result is inconsistent with the result concluded by AL-Haroot (2018). It indicates that the job does not provide the opportunity to make decisions independently. Statement (5) states the following: "academic leaders bear the responsibility for implementing the decisions they participated in". The mean of the latter statement is (3.39) which is moderate. The latter result is attributed to the lack of experience among academic leaders. The latter result is inconsistent with the result concluded by Al-Zamili (2015). The third area: self-motivation

Arithmetic mean, and standard deviations are calculated to identify the extent of practicing administrative empowerment by academic leaders in private universities in Amman, Jordan in terms of self-motivation. Table (4) presents those values

Table (4): The extent of practicing administrative empowerment by academic leaders in private universities in Amman, Jordan in terms of self-motivation

\begin{tabular}{|l|l|l|l|l|l|}
\hline No. & Area & Mean & Std. & Rank & Degree \\
\hline 4 & The university promotes positive behaviors among academic leaders. & 4.58 & 1.04 & 1 & $\begin{array}{l}\text { Very } \\
\text { high }\end{array}$ \\
\hline 5 & $\begin{array}{l}\text { The university raises the motivation of academic leaders to } \\
\text { contribute to achieving its goals. }\end{array}$ & 4.32 & 0.91 & 2 & $\begin{array}{l}\text { Very } \\
\text { high }\end{array}$ \\
\hline 2 & $\begin{array}{l}\text { The university supports the capabilities of academic leaders by } \\
\text { providing adequate resources for their development. }\end{array}$ & 3.96 & 0.93 & 3 & high \\
\hline 6 & $\begin{array}{l}\text { The university appreciates the efforts of academic leaders in working } \\
\text { in a classy manner. }\end{array}$ & 3.93 & 1.01 & 4 & high \\
\hline 3 & $\begin{array}{l}\text { The salary earned by academic leaders is proportional to the effort } \\
\text { expended at work. }\end{array}$ & 3.81 & 0.82 & 5 & high \\
\hline 1 & $\begin{array}{l}\text { The university provides academic leaders with a sense of job } \\
\text { security. }\end{array}$ & 3.78 & 0.87 & 6 & high \\
\hline Total & 4.06 & 0.9 & & high \\
\hline
\end{tabular}

Based on table (4), the arithmetic means are within the range of (4.58-3.78). Statement (4) states the following: "the university promotes positive behaviors among academic leaders," The mean of the latter statement is (4.58). The latter result is attributed to the fact that private Jordanian universities believe in the concept of reinforcement and its effect on behavior among academic leaders. The latter result is consistent with the result concluded by AlHamidi (2016). The mean of statement (1) is (3.78) which is high. The latter result is inconsistent with the result concluded by (AL-Haroot, 2018).

\section{Fourth Domain: Effective Communication}

Arithmetic mean, and standard deviations are calculated to identify the extent of practicing administrative 
empowerment by academic leaders in private universities in Amman, Jordan in terms of effective communication. Table (5) presents those values

\begin{tabular}{|c|c|c|c|c|c|}
\hline No. & Area & Mean & Std. & Rank & Degree \\
\hline 3 & $\begin{array}{l}\text { The university facilitates access for academic leaders to various data } \\
\text { and information. }\end{array}$ & 4.68 & 0.75 & 1 & $\begin{array}{l}\text { Very } \\
\text { high }\end{array}$ \\
\hline 5 & $\begin{array}{l}\text { The university is interested in finding effective and advanced means } \\
\text { of communicating with academic leaders. }\end{array}$ & 4.13 & 1.03 & 2 & high \\
\hline 1 & Instructions to academic leaders are clear. & 3.94 & 0.97 & 3 & high \\
\hline 2 & $\begin{array}{l}\text { Effective communication plays an important role in exchanging } \\
\text { information and experiences between leaders easily and without } \\
\text { restrictions. }\end{array}$ & 3.87 & 0.81 & 4 & high \\
\hline 4 & Academic leaders can share information about business problems. & 3.59 & 0.94 & 5 & high \\
\hline 6 & Various means of communication within the university are used & 3.46 & 1.02 & 6 & high \\
\hline \multicolumn{2}{|r|}{ Total } & 3.95 & 0.92 & & high \\
\hline
\end{tabular}

Based on table (5), the arithmetic means are within the range of (4.68-3.46). Statement (3) states the following: "It is easy for academic leaders to access various data and information," The mean of the latter statement is (4.68) which is very high. The latter result is attributed to the fact that the powers granted to academic leaders to access data and information are available and easy to access. It is attributed to the fact that private Jordanian universities are interested in having a database that includes all the information that academic leaders need to accomplish the work assigned to them. The latter result is inconsistent with the result concluded by (AL-Haroot, 2018).

Statement (6) states the following: "Various means of communication within the university are used". The mean of the latter statement is (3.46). The latter result indicates that Jordanian private universities seek providing all the needed means of communication. That shall enable employees to deliver information fast. The latter result is inconsistent with the result concluded by (Al-Zamili, 2015).

\section{The results related to the second question}

Q.2. What is the extent of achieving a competitive advantage by academic leaders in private universities in Amman, Jordan from the persepctive of faculty members?

To answer this question, the arithmetic mean and standard deviations are calculated and presented in table (6) below:

Table (6): The extent of achieving a competitive advantage by academic leaders in private universities in

Amman, Jordan from the persepctive of faculty members

\begin{tabular}{|c|l|c|c|c|c|}
\hline No. & \multicolumn{1}{|c|}{ Item } & Mean & Std. & Rank & Degree \\
\hline 10 & $\begin{array}{l}\text { The university provides academic leaders with the freedom to } \\
\text { experiment with new ideas. }\end{array}$ & 4.47 & 0.91 & 1 & $\begin{array}{l}\text { Very } \\
\text { high }\end{array}$ \\
\hline 2 & $\begin{array}{l}\text { The university provides academic leaders with the financial means } \\
\text { to implement new creative ideas. }\end{array}$ & 4.39 & 1.01 & 2 & $\begin{array}{c}\text { Very } \\
\text { high }\end{array}$ \\
\hline 4 & $\begin{array}{l}\text { The university provides an educational administrative climate that } \\
\text { helps develop creative thinking. }\end{array}$ & 4.24 & 0.82 & 3 & $\begin{array}{l}\text { Very } \\
\text { high }\end{array}$ \\
\hline 9 & $\begin{array}{l}\text { The university provides academic leaders with feedback on their } \\
\text { performance to overcome their weaknesses. }\end{array}$ & 4.23 & 0.79 & 4 & $\begin{array}{l}\text { Very } \\
\text { high }\end{array}$ \\
\hline 1 & $\begin{array}{l}\text { The university encourages academic leaders to take initiative to } \\
\text { improve services. }\end{array}$ & 4.11 & 0.74 & 5 & high \\
\hline 11 & $\begin{array}{l}\text { The university responds to the needs of the labor market by opening } \\
\text { new specializations. }\end{array}$ & 4.03 & 0.84 & 6 & high \\
\hline 3 & The university is keen on developing the quality of its outputs. & 4.03 & 0.81 & 7 & high \\
\hline 12 & $\begin{array}{l}\text { Academic leaders make decisions after careful consideration of the } \\
\text { surrounding environment. }\end{array}$ & 3.96 & 0.92 & 8 & high \\
\hline 7 & $\begin{array}{l}\text { The university is characterized by rapid response in adopting } \\
\text { information technology in its administrative operations. }\end{array}$ & 3.81 & 0.84 & 9 & high \\
\hline 6 & The university keeps abreast of developments. & 3.7 & 0.71 & 10 & high \\
\hline 8 & $\begin{array}{l}\text { The university is keen to take into account the cost dimension in } \\
\text { providing services. }\end{array}$ & 3.62 & 0.78 & 11 & high \\
\hline 13 & $\begin{array}{l}\text { The university is committed to the quality dimension in providing its } \\
\text { services. }\end{array}$ & 3.36 & 0.83 & 12 & Moderate \\
\hline 5 & Academic leaders seek to constantly develop their future plans. & 3.32 & 0.86 & 13 & Moderate \\
\hline & \multicolumn{1}{|c|}{ Total } & 0.83 & High \\
\hline
\end{tabular}

Based on table (6), the extent of achieving a competitive advantage by academic leaders in private universities 
in Amman, Jordan from the persepctive of faculty members is high. That's because the ovreall mean is 3.94. The means are within the range of (4.47- 3.32). Statement (10) states the following: "the university provides the academic leaders with the freedom to experiment with new ideas," The mean of the latter statement is (4.47) which is very high. That's attributed to the fact that private Jordanian universities provide an environment and climate that promote collaboration, and creativity. The latter result is consistent with the result concluded by Al-Helaa et al. (2017).

Statement (6) states the following: ' academic leaders seek to continuously develop their future plans'. The mean of the latter statement is (3.32) which is moderate. The researcher attributes the latter result to the fact that academic leaders in private Jordanian universities must develop plans in order to handle future challenges. The latter result is inconsistent with the result concluded by this result differs with the results of the study (Al-Shammari, 2018).

\section{Results related to the third question}

Q.3. Is there any significant relationship -at the statistical significance level of $(a=0.05)$ - between the extent of practicing administrative empowerment by academic leaders from one hand and the achievment of a competitive advantage in private universities in Amman, Jordan from another hand from the perspective of faculty members?

The Pearson correlation coefficient was used to measure the relationship between administrative empowerment and competitive advantage in private Jordanian universities in the Amman Governorate from the faculty members 'viewpoint, and Table (7) shows that:

Table (7): Pearson Correlation Coefficient to explore the relationship between administrative empowerment and competitive advantage in private Jordanian universities

\begin{tabular}{|c|l|c|c|}
\hline \multirow{2}{*}{ No. Area } & \multicolumn{2}{|c|}{$\begin{array}{c}\text { The total score of the competitive } \\
\text { advantage questionnaire }\end{array}$} \\
\cline { 3 - 4 } & & Correlation coefficient & Sig. \\
\hline 1 & Effective Communication & $* * 0.608$ & 0.000 \\
\hline 2 & Participate in decision-making & $* * 0.672$ & 0.000 \\
\hline 3 & Delegation of authority & $* * 0.625$ & 0.000 \\
\hline 4 & Self motivation & $* * 0.631$ & 0.000 \\
\hline \multicolumn{2}{|c|}{ Total } & $* * 0.770$ & 0.000 \\
\hline
\end{tabular}

Based on table (7), there is a positive significant relationship -at the statistical significance level of $(\alpha \leq 0.01)$ between administrative empowerment dimensions and competitive advantage. That is because the value of the correlation coefficient is $(0.77)$. The latter result is consistent with the result concluded by (Al-Salahat, 2017) and the study (Al-Zamili, 2015).

\section{Results related to the fourth question}

Q.4. Is there any statistically significant difference-at the statistical significance level of $(\mathrm{a}=0.05)$ - between the respondents' attitudes towards administrative empowerment which can be attributed to (gender, rank or experience)?

\section{Gender:}

To explore the results in this regard, arithmetic mean and standard deviations are calculated and the t-test was conducted. The values are shown in table (8)

Table (8): T-test for exploring whether there's any statistically significant difference-at the statistical significance level of $(\mathrm{a}=0.05)$ - between the respondents' attitudes towards administrative empowerment which can be attributed to (gender.

\begin{tabular}{|c|c|c|c|c|c|c|}
\hline No. & \multicolumn{2}{|l|}{ Area } & Mean & Std. & (T) Value & Sig. \\
\hline \multirow{2}{*}{1} & \multirow{2}{*}{ Effective Communication } & Male & 3.94 & 1.01 & \multirow{2}{*}{0.08} & \multirow{2}{*}{$* 0.000$} \\
\hline & & Female & 3.73 & 0.76 & & \\
\hline \multirow{2}{*}{2} & \multirow{2}{*}{ Participate in decision-making } & Male & 3.81 & 1.18 & \multirow{2}{*}{-0.23} & \multirow{2}{*}{$* 0.04$} \\
\hline & & Female & 3.40 & 0.98 & & \\
\hline \multirow{2}{*}{3} & \multirow{2}{*}{ Delegation of authority } & Male & 3.52 & 1.05 & \multirow{2}{*}{-0.14} & \multirow{2}{*}{$* 0.01$} \\
\hline & & Female & 3.09 & 1.02 & & \\
\hline \multirow{2}{*}{4} & \multirow{2}{*}{ Self motivation } & Male & 3.06 & 1.19 & \multirow{2}{*}{-1.04} & \multirow{2}{*}{$* 0.03$} \\
\hline & & Female & 2.88 & 1.19 & & \\
\hline \multirow{2}{*}{\multicolumn{2}{|c|}{ Total }} & Male & 3.58 & 1.98 & \multirow{2}{*}{-0.74} & \multirow{2}{*}{$* 0.02$} \\
\hline & & Female & 3.28 & 0.94 & & \\
\hline
\end{tabular}

Based on table (8), there is a statistically significant difference-at the statistical significance level of $(a=0.05)$ between the respondents' attitudes towards administrative empowerment which can be attributed to (gender). That is because the $t$-value is -0.74 and the significance level is 0.02 . The latter difference is for the favor of males. The 
latter result indicates that males are empowered more than females. The latter result is inconsistent with the result concluded by (Al-Zamili, 2015).

\section{Academic rank:}

The unilateral analysis of variance test was conducted. It aims to identify whether there is any statistically significant difference-at the statistical significance level of $(\mathrm{a}=0.05)$ - between the respondents' attitudes towards administrative empowerment which can be attributed to academic rank. Table (9) presents the results of the latter test.

Table (9): The results of the one-way ANOVA analysis to identify whether there is any statistically significant difference-at the statistical significance level of $(a=0.05)$ - between the respondents' attitudes towards administrative empowerment which can be attributed to academic rank

\begin{tabular}{|c|c|c|c|c|c|c|c|}
\hline No. & Area & $\begin{array}{l}\text { Source of } \\
\text { variance }\end{array}$ & $\begin{array}{l}\text { Sum of } \\
\text { squares }\end{array}$ & Df. & $\begin{array}{c}\text { Mean } \\
\text { square }\end{array}$ & $\begin{array}{c}(\mathrm{F}) \\
\text { Value }\end{array}$ & Sig. \\
\hline \multirow{3}{*}{1} & \multirow{3}{*}{ Effective Communication } & Between groups & 0.376 & 2 & 0.188 & \multirow{3}{*}{0.596} & \multirow{3}{*}{0.522} \\
\hline & & Within groups & 64.987 & 334 & 0.315 & & \\
\hline & & Total & 65.363 & 336 & & & \\
\hline \multirow{3}{*}{2} & \multirow{3}{*}{$\begin{array}{l}\text { Participate in decision- } \\
\text { making }\end{array}$} & Between groups & 0.530 & 2 & 0.265 & \multirow{3}{*}{0.960} & \multirow{3}{*}{0.385} \\
\hline & & Within groups & 56.869 & 334 & 0.276 & & \\
\hline & & Total & 57.399 & 336 & & & \\
\hline \multirow{3}{*}{3} & \multirow{3}{*}{ Delegation of authority } & Between groups & 1.15 & 2 & 0.576 & \multirow{3}{*}{2.255} & \multirow{3}{*}{0.107} \\
\hline & & Within groups & 52.616 & 334 & 0.255 & & \\
\hline & & Total & 53.768 & 336 & & & \\
\hline \multirow{3}{*}{4} & \multirow{3}{*}{ Self motivation } & Between groups & 0.485 & 2 & 0.243 & \multirow{3}{*}{0.815} & \multirow{3}{*}{0.444} \\
\hline & & Within groups & 61.284 & 334 & 0.297 & & \\
\hline & & Total & 61.769 & 336 & & & \\
\hline \multirow{3}{*}{\multicolumn{2}{|c|}{ Total }} & Between groups & 0.570 & 2 & 0.285 & \multirow{3}{*}{1.708} & \multirow{3}{*}{0.184} \\
\hline & & Within groups & 34.342 & 334 & 0.166 & & \\
\hline & & Total & 34.912 & 336 & & & \\
\hline
\end{tabular}

Based on table (9), there isn't any statistically significant difference-at the statistical significance level of $(\mathrm{a}=0.05)$ - between the respondents' attitudes towards administrative empowerment which can be attributed to academic rank. That's because the calculated $\mathrm{f}$ value is (1.708) and the significance value us $(0.184)$. The latter result indicates that respondents of all academic ranks have similar perceptions in this regard. The latter result is consistent with the result concluded by (Al-Salahat, 2017).

\section{Experience}

The unilateral analysis of variance test was applied to identify whether there is any statistically significant difference-at the statistical significance level of $(\mathrm{a}=0.05)$ - between the respondents' attitudes towards administrative empowerment which can be attributed to experience. Table (10) presents the result of the latter analysis.

Table (10): The results of the one way ANOVA analysis to identify whether there is any statistically significant difference-at the statistical significance level of $(\mathrm{a}=0.05)$ - between the respondents' attitudes towards administrative empowerment which can be attributed to experience

\begin{tabular}{|c|c|c|c|c|c|c|c|}
\hline No. & Area & $\begin{array}{l}\text { Source of } \\
\text { variance }\end{array}$ & $\begin{array}{l}\text { Sum of } \\
\text { squares }\end{array}$ & Df. & $\begin{array}{l}\text { Mean } \\
\text { square }\end{array}$ & $\begin{array}{c}\text { (F) } \\
\text { Value }\end{array}$ & Sig. \\
\hline \multirow{3}{*}{1} & \multirow{3}{*}{ Effective Communication } & Between groups & 0.152 & 2 & 0.076 & \multirow{3}{*}{0.361} & \multirow{3}{*}{0.698} \\
\hline & & Within groups & 43.175 & 334 & 0.210 & & \\
\hline & & Total & 43.327 & 336 & & & \\
\hline \multirow{3}{*}{2} & \multirow{3}{*}{$\begin{array}{l}\text { Participate in decision- } \\
\text { making }\end{array}$} & Between groups & 0.117 & 2 & 0.059 & \multirow{3}{*}{0.252} & \multirow{3}{*}{0.778} \\
\hline & & Within groups & 48.062 & 334 & 0.233 & & \\
\hline & & Total & 48.179 & 336 & & & \\
\hline \multirow{3}{*}{3} & \multirow{3}{*}{ Delegation of authority } & Between groups & 0.303 & 2 & 0.151 & \multirow{3}{*}{1.035} & \multirow{3}{*}{0.357} \\
\hline & & Within groups & 30.133 & 334 & 0.146 & & \\
\hline & & Total & 30.436 & 336 & & & \\
\hline \multirow{3}{*}{4} & \multirow{3}{*}{ Self motivation } & Between groups & 0.479 & 2 & 0.239 & \multirow{3}{*}{1.261} & \multirow{3}{*}{0.287} \\
\hline & & Within groups & 39.080 & 334 & 0.190 & & \\
\hline & & Total & 39.559 & 336 & & & \\
\hline \multirow{3}{*}{\multicolumn{2}{|c|}{ Total }} & Between groups & 0.144 & 2 & 0.072 & \multirow{3}{*}{0.636} & \multirow{3}{*}{0.533} \\
\hline & & Within groups & 23.377 & 334 & 0.112 & & \\
\hline & & Total & 23.521 & 336 & & & \\
\hline
\end{tabular}


Based on table (10), there isn't any statistically significant difference-at the statistical significance level of $(a=0.05)$ - between the respondents' attitudes towards administrative empowerment which can be attributed to experience. The calculated $\mathrm{F}$ value is 0.636 and the significance value is 0.533 . The latter result is consistent with the result concluded by AL-Haroot (2018).

\section{The results related to the fifth question}

Q.5. Is there any statistically significant difference-at the statistical significance level of $(a=0.05)$ - between the respondents' attitudes towards achieving a competitive advantage which can be attributed to (gender, rank or experience)?

\section{Gender:}

The arithmetic averages and standard deviations are calculated and the t-test was conducted to explore whether there is a statistically significant difference-at the statistical significance level of $(a=0.05)$ - between the respondents' attitudes towards achieving a competitive advantage which can be attributed to (gender). Table (11) presents the results in this regard.

Table (11): The arithmetic means and standard deviations and the t-test results to explore whether there is a statistically significant difference-at the statistical significance level of $(a=0.05)$ - between the respondents' attitudes towards achieving a competitive advantage which can be attributed to (gender).

\begin{tabular}{|c|c|c|c|c|c|}
\hline \multicolumn{2}{|c|}{ Area } & Mean & Std. & $(\mathrm{T})$ Value & Sig. \\
\hline \multirow{2}{*}{ Competitive advantage } & Male & 4.128 & 0.371 & \multirow{2}{*}{1.414} & \multirow{2}{*}{0.159} \\
\cline { 2 - 4 } & Female & 4.241 & 0.409 & & \\
\hline
\end{tabular}

Based on table (11), there isn't any statistically significant difference-at the statistical significance level of $(\mathrm{a}=0.05)$ - between the respondents' attitudes towards achieving a competitive advantage which can be attributed to (gender).

Based on table (11), there isn't any statistically significant difference-at the statistical significance level of $(\mathrm{a}=0.05)$ - between the respondents' attitudes towards achieving a competitive advantage which can be attributed to (gender). The t-value is 1.141 and the significance value is 0.159 . This result is inconsistent with the results concluded by Al-Salahat (2017).

\section{Academic rank:}

The unilateral analysis of variance test was applied to identify whether there is any statistically significant difference-at the statistical significance level of $(\mathrm{a}=0.05)$ - between the respondents' attitudes towards achieving a competitive advantage which can be attributed to academic rank. Table (12) presents the results in this regard.

Table (12): The results of the one-way ANOVA analysis to identify whether there is any statistically significant difference-at the statistical significance level of $(a=0.05)$ - between the respondents' attitudes towards achieving a competitive advantage which can be attributed to academic rank

\begin{tabular}{|c|c|c|c|c|c|c|}
\hline \multirow{2}{*}{ Area } & Source of variance & $\begin{array}{c}\text { Sum of } \\
\text { squares }\end{array}$ & Df. & $\begin{array}{c}\text { Mean } \\
\text { square }\end{array}$ & $\begin{array}{c}\text { (F) } \\
\text { Value }\end{array}$ & Sig. \\
\hline \multirow{3}{*}{ Competitive advantage } & Between groups & 0.644 & 2 & 0.322 & \multirow{3}{*}{2.023} & \multirow{3}{*}{0.136} \\
\cline { 2 - 6 } & Within groups & 24.208 & 334 & 0.159 & \multirow{2}{*}{2.023} \\
\cline { 2 - 7 } & Total & 24.853 & 336 & & \\
\hline
\end{tabular}

Based on table (12), there isn't any statistically significant difference-at the statistical significance level of $(\mathrm{a}=0.05)$ - between the respondents' attitudes towards achieving a competitive advantage which can be attributed to academic rank. That's because the $\mathrm{f}$ value is (2.023) and the significance value is 0.136 . The latter result is consistent with the results concluded by (Al-Shammari, 2014).

\section{Experience}

The unilateral analysis of variance test was conducted to identify whether there is any statistically significant difference-at the statistical significance level of $(\mathrm{a}=0.05)$ - between the respondents' attitudes towards achieving a competitive advantage which can be attributed to experience. Table (13) shows those values:

Table (13): The results of the one way ANOVA analysis for identifying whether there is any statistically significant difference-at the statistical significance level of $(\mathrm{a}=0.05)$ - between the respondents' attitudes towards achieving a competitive advantage which can be attributed to experience

\begin{tabular}{|c|c|c|c|c|c|c|}
\hline \multirow{2}{*}{ Area } & Source of variance & $\begin{array}{c}\text { Sum of } \\
\text { squares }\end{array}$ & Df. & $\begin{array}{c}\text { Mean } \\
\text { square }\end{array}$ & $\begin{array}{c}(\mathrm{F}) \\
\text { Value }\end{array}$ & Sig. \\
\hline \multirow{3}{*}{ Competitive advantage } & Between groups & 1.308 & 2 & 0.641 & \multirow{2}{*}{0.890} & \multirow{2}{*}{0.40} \\
\cline { 2 - 7 } & Within groups & 23.114 & 334 & 0.732 & \multirow{2}{*}{0.890} \\
\cline { 2 - 7 } & Total & 24.964 & 336 & & & \\
\cline { 2 - 6 }
\end{tabular}

Based on table (13), there isn't any statistically significant difference-at the statistical significance level of $(a=0.05)$ - between the respondents' attitudes towards achieving a competitive advantage which can be attributed to experience. That is because the $\mathrm{F}$ value is 0.890 and the signifiacne value is 0.40 . The result is consistent with 
the result concluded by Al-Salahat (2017).

\section{Recommendations:}

In light of the previous results, the researcher recommends the following:

1) Providing employees at Jordanian universities with adequate opportunities to express their opinions and participate in the decision-making process

2) More power should be delegated to employees at Jordanian universities

3) Exerting more efforts to empower females at Jordanian universities and increase their participation in decision-making.

4) Conducting more studies about the relationship between administrative empowerment and competitive advantage.

\section{References}

Abd al-Hadi, A. \& Hatata, U. (2012), Empowering Academic Leaders at Kafr El-Sheikh University: A Case Study. Education Journal, Egypt, 15 (35), 201-279.

Abd al-Wahab, H. (2014). The role of human resources management in achieving competitive advantage in organizations. $1^{\text {st }}$ ed., Amman: Dar Al-Ayyam for Publishing and Distribution.

Badah, A. (2012). Relationship between the knowledge management processes and the administrative empowerment with the employees of the ministry of higher education and scientific research-Jordan. European Scientific Journal, ESJ ,8(28), 1-62.

Chang, C. (2016). The influence of corporate environmental ethics on competitive advantage: The Meditation Role of Green Innovation, Journal of Business Ethics, 104 (2), 12-23.

Al-Dughmi, H. (2019). Administrative empowerment in institutional excellence. (Unpublished Master Thesis), Al al-Bayt University, Mafraq, Jordan.

Al-Hamidi, M. (2016). Job empowerment and its relationship to organizational loyalty among faculty members of the College of Education at Taif University from their point of view. Specialized International Journal, 5 (4), 236-266.

AL-Haroot, S. (2018). Managing change among government secondary school principals and its relationship to administrative empowerment from the teachers' point of view in Madaba Governorate. (Unpublished Master Thesis), Middle East University, Amman, Jordan.

Al hilaa, A., Al Shobakib, M., Abu Amuna, Y. \& Abu Naser, S. (2017). Organizational Excellence in Palestinian Universities of Gaza Strip, International Journal of Information Technology and Electrical Engineering, 6(4), 20-30.

Hill, C. \& Jones, G. (2008). Strategic Management: An Integrated Approach",8th ed, Houghton Mifflin Company, New York.

Jallab, I. \& Al-Hussaini, K. (2013). Empowerment and Inclusion Department. $1^{\text {st }}$ ed., Amman: Dar Al-Safa for Publishing and Distribution.

Al-Kubaisi, J., May, F. \& Al-Khafaji, S. (2017). Degree of need for managers working in directorates of education to develop their skills to practice administrative empowerment, Journal of the College of Education for Girls, University of Baghdad, Iraq 28 (1), 1-15.

Alnaweigah, A. (2013). The Impact of Knowledge Management Functions on the Organizational Excellence from the Perspective of the University of Al-Taif Staff, Interdisciplinary Journal of Contemporary Research in Business, 5(3), 170-192.

Pitts, R. \& Lee, D. (1996)."Strategic Management Building and Sustaining Competitive Advantage" West Publishing. Co. U.S.A.

Porter, M. (2006). Strategy and the internet. Harvard Business Review, 79(3),12-53.

Al-Salahat, N. (2017). Administrative empowerment among academic leaders and its relationship to competitive advantage from the viewpoint of faculty members at Middle East University. (Unpublished Master Thesis), Middle East University, Amman, Jordan.

Al-Shammari, A. (2018). The Impact of Administrative Empowerment on Achieving Competitive Capabilities: A Case Study of Kuwait University. (Unpublished Master Thesis), Al al-Bayt University, Mafraq, Jordan.

Al-Shammari, E. (2014). The degree of availability of intellectual capital and its relationship to the degree of achieving a competitive advantage in Kuwaiti private universities from the viewpoint of its faculty members. (Unpublished Master Thesis), Middle East University, Amman, Jordan.

Al-Shtatikhi, I. (2016). Administrative empowerment of educational leaders in kindergartens and its relationship to the practice of knowledge management processes. Journal of the Association of Arab Universities for Education and Psychology, Damascus, Syria, 14 (3), 42-101.

Smith, E. \& Greyling, A. (2006). Empowerment perceptions of educational managers from previously disadvantaged primary and high schools: an explorative study, South African Journal of Education, 26(4), 
595-607.

Taleb, A. (2012). Blue Ocean Strategy and Sustainable Competitive Advantage. $1^{\text {st }}$ ed., Amman: Al-Hamed House for Publishing and Distribution.

Wadi, H. (2013) Administrative Empowerment in the Modern Era. $1^{\text {st }}$ ed., Amman: Wael House for Publishing and Distribution.

Weshah, H. (2012). The Perception of Empowerment and Delegation of Authority by Teachers in Australian and Jordanian Schools: A Comparative Study, European Journal of Social Sciences, 31(3), 359-375.

Wheelen, T. \& Hunger, J. (2012). Strategic Management and Business Policy: Concepts and Cases, 13th, New Jersey, Person Prentice- Hall.

Al-Zamili, M. (2015). The degree of administrative empowerment of secondary school principals in Gaza governorates and its relationship to their level of job satisfaction. (Unpublished Master Thesis), Islamic University, Gaza, Palestine. 